\section{NATURE}

No. 3844

SATURDAY, JULY 3, 1943

Vol. 152

\section{CONTENTS}

\section{Food and the Strategy of Peace}

Education: for Whom and for What?

A Study of the Robin. By Prof. Julian Huxley, F.R.S.

Gem Testing .

The First Stage from. Barbarism. By Miss L. Evelyn Cheesman

Shortened Physics. By Dr. L. F. Richardson, F.R.S.

Paper Mill Laboratory Technique. By Dr. V. G. W. Harrison

Science in South-West China : 1. The Physico-Chemical Sciences. By Dr. Joseph Needham, F.R.S.

The Lister Institute of Preventive Medicine : Fifty Years Research Activity. By Sir John Ledingham, C.M.G., F.R.S.

Ascorbic Acid in Dehydrated Foods. By Dr. L. W. Mapson

Apparent Vitamin C in Certain Foodstuffs. By Dr. Frank Wokes, Joan G. Organ, Jeanette Duncan and Dr. F. C. Jacoby

Obituary :

Prof. Charies Schuchert. By Miss Muriel A. Arber

News and Views

Letters to the Editors:

Thermal Scattering of X-Rays by Crystals.-G. H. Begbie and Prof. M. Born, F.R.S.; Dr. K. Lonsdale

New X-Ray Evidence of the Nature of the Structural Changes in Cold-worked Metals.-Dr. H. Lipson and A. R. Stokes

Value of the pF Scale of Soil Moisture for Expressing the Soil Moisture Relations of Wireworms. -A. C. Evans

Effect of p-Aminobenzoic Acid on Defective Cultures of Bacteria.-Dr. J. Ungar . . . .

Archæology as a Science.-Prof. V. Gordon Childe, F.B.A.

Fortieth Anniversary of the University of Peiping. -Prof. Ch'ang Ch'ing-Yueh, Dr. Joseph Needham, F.R.S., and Prof. Sun Yün-Chu

Research Items

Cancer Research

Protective Systems for Rural Electrical Distribution

The Termites of Australia. By Dr. A. D. Imms, F.R.S.

\title{
FOOD AND THE STRATEGY OF PEACE
}

$\mathrm{T}$ HE United Nations Conference on Food and Agriculture which has just ended at Hot Springs, Virginia, brought together representatives of forty four nations to consider the world problem of food distribution after the War. It has been described, not inaccurately, by the editors of Fortune as the first of the peace conferences to end the War, and for the first time in history we are witnessing the planning of the strategy of peace while the objectives of war are still far from their fulfilment. The Conference has yet to be followed by action, it is true, but on its face value its declarations and decisions give reasonable ground for the belief that an important blow has been struck for sanity in world economics.

The recommendations show that most of the time and expert knowledge of the delegates to the Conference were devoted to the problem of providing more and better food for 2,000 million people to eat. Almost all their proposals for the expansion of production, the improvement of nutrition and the increase of consumption are specifically directed to this end. The prior charge on each country will be 13 to provide the foods of high nutritional value such as milk, other dairy produce, vegetables and fruit, which are mostly perishable and best produced as near as possible to the centres of production. The want and need of these protective foods is almost unlimited. Beyond this basic domestic priority, consumption needs must be met from the most efficient sources of production wherever they may be found, with specific safeguards for the conserva. tion of soil and its fertility.

Essentially this programme is a manifesto for freer trade and the international division of labour. Equally it is a programme of full employment-the development of industries and of purchasing "power in backward areas as well as the maximum output of the right foodstuffs in the right places. It is not a policy of laisser-faire or of cut-throat competition, and although guarantees of stable prices to efficient producers to prevent the collapses which have been a bane in the past are essential to success, the protection of producers and restriction of supply by high tariffs or quantitative restrictions on imports must be firmly excluded. The protection of consumers and the maintenance of demand by social security measures or subsidies to special classes must be the weapons of policy.

The principal decision of the Conference is the creation of a permanent international organization, on the lines of the International Labour Organisation, to secure collaboration on measures to increase production, distribution and consumption of food. Until the permanent organization can be established, an interim commission is to function in Washington, meeting not later than July 15. This Commission will be responsible for the promotion and co-ordination of research, and for the collection and dissemina tion of information. It will submit to the individual Governments recommendations for action along the 
lines agreed by the Conference, and will examine such questions as the development of agricultural resources, commodity arrangements, consumer cooperatives, land tenure and other subjects considered at the Conference:

Besides this section concerned with the permanent machinery to implement its recommendations, the Conference was organized in three other sections, each divided into a number of committees, responsible for examining particular aspects of the general problem.

The report of the first section, on consumption levels and requirements, stresses the relation between malnutrition and poverty and gives a picture of "world-wide under-consumption, malnutrition and its attendant evils". Three-quarters of the 1,150 million inhabitants of Asia are living below decent health standards; malnutrition exists among the lower income groups of the United States and Europe; there are widespread deficiencies in tropical Africa, the West Indies and other colonial territories, and the War has aggravated a situation already serious. Without formulating a uniform set of dietary standards for general application, certain broad principles are laid down, and such standards as those evolved by the League of Nations Technical Commission on Nutrition are universally applicable. Advances in nutritional science permit the establishment of minimum dietary requirements in terms of calorie, protein, mineral and vitamin content. Government promotion of systematic education in food values, special provision for pregnant women, nursing mothers, infants and adolescents and the development of community services, school meals and factory canteens are recommended.

The second section, which examined the expansion of production and adaptation to consumption needs, distinguishes between the short-term and the longtern objectives. First, it recommends an immediate increase wherever possible in the acreage of crops for direct human consumption, even at the expense of postponing the replenishment of livestock herds. While the shortages continue, the governments, individually and collectively, should endeavour to co-ordinate national production policies and the means of transport and distribution, and should take measures to prevent speculation and price fluctuations. Countries which, owing to their freedom from the impact of war, have been producing more than their normal output should maintain or expand their production and develop the manufacture of farm machinery and fertilizers.

The period of transition will involve considerable adjustments in policies. The long-term policy of each nation should be to increase the efficiency of production through better farming methods, measures for soil conservation, the encouragement of research, and the exploitation of undeveloped areas through land clearance, drainage and irrigation projects; and to introduce changes designed to foster the production at home of protective and relatively perishable foodstuffs. Nations should not attempt artificially to produce nutritionally desirable foods which can easily be obtained elsewhere. Besides measures designed to improve agricultural efficiency and promote research, this section of the Conference recommends that, to facilitate occupational adjustments, countries with large populations in relation to their agriculture should develop suitable industries for processing and preserving their own produce, and should be assisted to export processed articles rather than raw materials, and to import machinery and tools.

The recommendations of the third section, on the facilitation and improvement of distribution, are less definite, depending as they do on international agreement in the wider field of reconstruction. The Conference recognizes that the key to the long-term problem lies in full employment, with generally increased purchasing power and improved standards of living. The need for maintaining a balance between agriculture and industry is recognized, and international trade barriers and restrictions are denounced. In the immediate post-war period it will be necessary to ensure the most economic distribution of available supplies and to avoid price fluctuations and un. restrained competition. Under-nutrition will necessitate international action on a large scale, and international commodity arrangements will be necessary : these should allow effective representation of consumers, the maintenance of adequate reserves and the orderly disposal of surpluses. Other recommendations are international standardization in methods of processing, preserving, storing, packing and transport ; measures for protecting the consumer from unfair trade practices; and full use of such war-time developments as dehydration.

So much for the general programme, the technical soundness of which can scarcely be questioned. The translation of recommendations into action, however, involves the overcoming of long-standing political obstacles, national and sectional. While, for example, the maintenance of health in Britain during the War shows what can be achieved through a scientific nutrition policy and the planned distribution of basic foodstuffs, in Britain no less than elsewhere agriculture is unbalanced and distorted, and with vested interests created in uneconomic farming. The farming forced on nations by war-time scarcities and the severance of communications is poles apart from the programme of abundance that co-operation and common sense could devise in a peaceful world, and is dangerously close to the narrow nationalistic aspirations of politicians and producers.

That is the first issue upon which the Governments of the world must fasten. To translate into specific terms this vision of an efficient and fruitful world agriculture, based on the expansion of world production according to a functional division of tasks, will demand not only all the help that the proposed permanent international organization can give it, but also the understanding support of public opinion everywhere. That the public interest must overlay discussion is a principle that must be firmly applied. Fortunately there are already welcome signs that education in this matter is proceeding apace. The recent Fortune report on "Relations with Europe" is an American example. Recognition of the importance of widening the areas of free trade and, when the 
Anglo-American and the European free-trade areas are well established, linking them and making them one, together with the recognition that reparations should be limited to payments in kind--the only reparations that make economic sense-are far in front of the outlook of 1919. On European economic and agricultural development the proposals of this Fortune report are strikingly in line with the broad trend of the Conference recommendations, and it is to be hoped that progressive opinion in Great Britain will not only welcome these proposals and recommendations but also lose no time in formulating a post-war agricultural policy in harmony with them.

The second point which requires emphasis is that the Conference reconnoitred only one sector of a large front. Originally it was intended that the Conference should confine its attention to post-war problems, but while in response to many appeals it considered also problems close at hand, it was not directly concerned with the relief measures that will be needed as new areas are liberated from the Axis. It could not ignore the problems of production which must be solved if food supplies on the scale needed to relieve hunger are to be forthcoming, but the Conference can only rightly be regarded as the fore. runner of other conferences of the United Nations, the work of which will be complementary to its own in laying down the strategy of the peace.

Food strategy is only a part, though an essential part, of that wide strategy, and the new world organization to be set up will provide the indispensable general staff for research, discussion of policy and advice to Governments. It will provide the centre for the collection of statistics and informa. tion and the co-ordination of policies. Such an organization is the more essential in view of the third point that stands out from the briefest review of the work of the Conference, namely, the intimate relation of this food strategy to the strategy of the attack on the problems of unemployment, disease and other evils which stand in the way of the realization of freedom from fear and from want. So far as Great Britain is concerned, this involves the special issues put forward in the Scott Report and ultimately in the Beveridge Report. Raising the standard of living and nutrition among all the nations must have profound effects on the domestic policy of every country in agriculture. Indeed the Conference enables us to glimpse something of the framework for a policy of general advance-for the establishment of full employment and social security.

We are brought, therefore, once more to realize that, complex as are the many problems involved in the establishment of a world order of full employment, social security and freedom from want, none of the interlocked problems can be considered in isolation. We must always have regard to the wider background, national and international, into which our decisions and policies have to fit. Moreover, as the work of the Conference clearly shows, it is that wider view that really gives us hope of a solution. Seen against the background of the Hot Springs Conference, assumption $C$ of the Beveridge Report has a reasonable prospect of fulfilment, and we may well hope that in further discussions on the Barlow Report, the Scott Report and the Beveridge Report, and in the overdue decisions as to the policy to be pursued, this larger background will not be forgotten but will assist in the formulation of bold policies and sound but courageous strategy.

There is evidence that this wider view is gaining acceptance. It is well put by Oswald Stein, chief of the Social Insurance Section, International Labour Office, in an article, "Building Society Security", which has recently been reprinted from the International Labour Review. Viewing the place of social security services in post-war reconstruction, he points out that such services should be conceived as an interdependent whole, intended to take care of, preserve and develop labour forces by ensuring their maximum productivity, and also their fair share in material progress even when their period of active participa. tion in production has passed. Moreover, social security is limited to the aims of preventing and controlling the common risks of life, and meeting those needs which are not only vital for the individual but at the same time essential for the moral and economic welfare of society as a whole. Such limitations exclude any collective guarantee tending to diminish the vital assets of individual effort and initiative.

Into this same framework fit the cardinal objectives outlined in the Fortune report: peace through a common military security; freedom through a common bill of rights ; prosperity through a common economic life, while here, as in the draft agreement for establishing the United Nations Relief and Rehabilitation Administration, is also the recognition that relief and rehabilitation will give the United Nations their first chance to transform their military alliance into a peaceful alliance with humanitarian and constructive aims. The relief scheme is the essential preliminary to the long-term programme of the Hot Springs Food Conference for realizing a world free from want, and it is at least a hopeful portent that the suggestions should come from an American periodical that the pooling of transport and communication facilities involved in relief and rehabilitation should be a step to the permanent unification of transport, and that the reappearance of autarchic tariffs, which clearly will not be allowed to interfere with the import of military and relief goods, should be postponed for ever.

Further evidence of the trend of American opinion can be found in the declaration adopted by the delegates of twenty-one countries at the InterAmerican Conference on Social Security at Santiago de Chile in September last, which related social security to the full achievements of the four freedoms and set forth a continental programme as well as visualizing a contribution to world solidarity and the attainment and maintenance of peace. In Great Britain a recent Planning broadsheet, "Employment for All", which cannot be analysed here, makes an important contribution to the discussion first of the guiding principles of a policy for full employment and second of the operation of those principles in the setting of the immediate post-war years. Even 
more important is the draft agreement for the creation of a United Nations Relief and Rehabilitation Administration which the United States Government, after consultation with the British, the Soviet and the Chinese Governments, has recently put before the United Nations.

This comprehensive plan for administering relief in the wake of the armies of liberation is of importance in relation to food strategy, for several reasons. It is the first step towards a balanced economy in which a. high level of consumption will prevent the piling up of great stocks of surplus goods in all the primary producing countries. Relief and rehabilitation is the opening phase of the post-war era, and the recent address of Herbert Lehman, at present director of the Foreign Relief and Rehabilitation Operations of the United States, who is expected to be the first director-general of the new organization, shows how American opinion is facing the situation.

Secondly, the proposals, like those of the Food Conference, indicate a clearer understanding of the continuity of war and peace. All such schemes imply the retention for some time after the War of controls over food, raw materials and transport, as well as some of the national rationing schemes. The organization of common action for peace as for war must be based on the pooling of available resources and a common policy, and a common control to govern their distribution. It should be the business of every citizen of goodwill to promote that understanding, and the Food Conference and the relief agreement supply abundant material for that work-a task which admittedly the British and American Governments should themselves undertake with more vigour and less diffidence than they have hitherto shown.

A third encouraging sign is not merely the shift in emphasis from the political and constitutional to the social and economic factors in post-war reconstruction, but also the attempt to work out the implications of this shift in emphasis on an international scale. These attempts to provide for the immediate needs of food, medical supplies and clothing, and then for the reconstitution of the economic life of Europe in a way offering means of livelihood to its peoples for the future, are far more urgent and far more hopeful than the fixing of frontiers, establishment or reestablishment of constitution and conclusion of international pacts which preoccupied the peace-makers at Versailles. The functional and strictly practical character of the organizations now being set up by the United Nations as the framework of their continued co-operation after the War encourages the hope that the lessons of the past are being learned. If further, profiting again by the failure in 1918 to use such tried machinery as the Allied Transport Council and Food Council, we turn to our post-war purposes such organizations as the various Combined Boards for Food, Shipping, Production and Raw Materials, and the regional organizations such as the Middle East Supply Centre, there should be every reason for confidence that, with the help of all this experience and this established machinery for advice and execution, it should be possible to gain time for the creation and growth of new loyalties and combina- tions of interest, in addition to national ties. Such an outlook will be of immense importance when the time comes for the establishment of new international organizations endowed with full authority to deal with problems of health, food and agriculture, which can only be effectively handled over areas transcending national frontiers. Large as may be the responsibilities of the world's Governments, there still lies on each citizen the responsibility of endeavouring to understand the implications of the situation and of assisting his fellows to grasp it. By these means full support may be obtained for necessary action, even if it may appear to threaten sectional or even narrowly national interests. This is not to suggest that love of one's country is a thing of the past. There is still room for patriotism, but there must in addition be love of humanity ; one can surely be built up on the well-tried foundations of the other, to provide an edifice in which there is safe lodging for world under. standing and peace.

\section{EDUCATION : FOR WHOM AND FOR WHAT?}

COME time ago a document which, rather in$O$ accurately, became known as the Board of Education's "Green Book", was issued in order that ideas on the future shape of Great Britain's educational system might be discussed and clarified. Copies were not, for what seem to have been quite sound reasons, to be obtained by any save selected bodies. Almost inevitably, however, it appears to have become the most widely known 'secret' document of modern times. The result, nevertheless, has justified its preparation and circulation: for, ever since its issue, all kinds of bodies have embodied their own suggestions in pamphlets of varying hues. The National Union of Teachers was one of those bodies, and, more than a year ago, published its own "Green Book" under the title of "Educational Reconstruction".

The difficulty with all these documents, however, is that they are couched in the language-or is it the jargon?-which the expert tends to use when talking to other experts. Dipping at random among the pages we may find a sentence like this: "In the interim we recommend that the principles of the present Grant Formula, which is a combination of a per capita and percentage grant, be continued". That is, doubtless, an excellent recommendation, and its effect, if it be accepted, may profoundly influence the education and prospects of thousands of students. But it is very doubtful whether it will stimulate any great interest or excitement in the breasts of the majority of parents who want improvements in the educational opportunities of their children but know little or nothing of the intricacies of the system which should produce those opportunities.

Clearly, if educational reconstruction is to be successful, parents must know what it is all about and be anxious to see it put into operation. They cannot do that unless the matter be explained 